ISSN: 2146-3042

DOI: $10.25095 /$ mufad.465942

\title{
Borsa İstanbul'da Kote Bireysel Emeklilik, Hayat Ve Hayat-Dışı Sigorta Şirketlerinin Hisse Senedi Fiyat Tahmininde Box-Jenkıns Yöntemi*
}

\author{
Fatma Esin KURT ${ }^{* *}$ \\ Serpil SENAL ${ }^{* * *}$
}

\section{ÖZET}

Türkiye sigortacılık sektörü üzerine yapılan bu çalışma, yatırımcılar, analistler ve bilgi edinmek isteyenlere borsada faaliyet gösteren sigorta şirketleri hakkında yol gösterici nitelikte olmayı amaç edinmiştir. Türkiye'de sigortacılık sektörünün genel yapısı ve Borsa İstanbul'da faaliyet gösteren sigorta ve bireysel emeklilik şirketlerinin geçmiş ve gelecekte olması beklenen durumları hisse senedi fiyatları bazında analiz edilmiştir. Analizde kullanılan Box-Jenkins Yöntemi gerçekleşen verilere en uygun ARIMA veri üretme sürecini bulmayı hedefleyen bir süreçtir. Box-Jenkins/ARIMA Yöntemi zaman serilerinin geçmiş değerlerinden ve geçmişte yapılan tahmin hatalarından, değişkenin gelecekte alabileceği değerini hesaplamaktadır. Bu çalışmada Borsa Istanbul'da kote toplam beşşirkete ait hisse senedi kapanış fiyatları analiz edilerek, gelecek bir yıl için fiyat tahminleri yapılmıştır. Anadolu Hayat Emeklilik A.Ş., Anadolu Anonim Türk Sigorta Şirketi ve Güneş Sigorta A.Ş. şirketlerine ait hisse senedi fiyat tahmininde Box-Jenkins/ARIMA modeli kullanıldı̆̆ında doğru sonuçlar verdiği belirlenmiştir.

Anahtar Kelimeler: Box-Jenkins Yöntemi, Zaman Serileri Analizi, Sigortacılık

JEL Sinıflandırması: C22, F37, G22.

\section{Box-Jenkins Method On Prediction Of Price Of Life, Non-Life And Pension Insurance Shares Quoted On Istanbul Stock Market}

\section{ABSTRACT}

This study is about insurance sector in Turkey is aimed to be guide to investors, examiners and to be informed people about to insurance companies at stock market. General past of in Turkey insurance sector and insurance companies and individual pension companies expected positions at past and future which active in BIST is analysed by the stock price. Box-Jenkins method which is used in analysis, is the best process aimed ARIMA data produced. The Box-Jenkins / ARIMA method computes the future value of the variable from the past values of the time series and past forecast mistakes. In this study, stock closing prices of the five companies listed on the Stock Exchange Istanbul is analyzed and price estimates made for the future. Anadolu Hayat Emeklilik, Anadolu Anonim Türk Sigorta Şirketi and Güneş Sigorta A.Ş.'s stock prices are used in this study for estimating future values and method gives the correct results for these companies.

Keywords: Box-Jenkins Method, Time Series Analysis, Insurance

Jel Classification: C22, F37, G22.

\footnotetext{
* Bu makale, "Borsa İstanbul'da Kote Bireysel Emeklilik, Hayat Ve Hayat-Dışı Sigorta Şirketlerinin Hisse Senedi Fiyat Tahmininde Box-Jenkıns Yöntemi” adlı doktora tezinden üretilmiştir. Bu tez çalışması SDÜ tarafından desteklenmiştir. Proje No: 3736-D1-13

** Dr . Fatma Esin Kurt, Mehmet Akif Ersoy Üniversitesi, esinkurt@mehmetakif.edu.tr

**** Doç.Dr. Serpil Senal, Süleyman Demirel Üniversitesi, serpilsenal@sdu.edu.tr
} 


\section{GİRiş}

Hayat sigortası, Hayat-Dışı Sigortalar ve son yıllarda oldukça yoğun talep gören bireysel emeklilik sistemi ile birlikte sigortacılık sektörü ülke ekonomilerinde oldukça büyük fon tutarlarına sahip bir branş olarak faaliyetlerine devam etmektedir. Sermaye piyasalarının da gelişmesiyle sigortacılık, ortaya çıktığı günlerdeki yardımlaşma vasfının yanında toplanan primlerin yatırım ve kredi amaçlı olarak kullanılmasıyla hızlı ivmelerle büyümeye devam eden bir sektördür. Sigortacılık sektörünün sağlıklı biçimde çalışması, ülke sanayisinin gelişmesinde önemli rol oynamaktadır. Özellikle şirketlerin olası risklerini sigorta ettirmeleri, gelecekteki faaliyetlerinin güvenli bir şekilde sürdürebilmeleri ve öz sermayelerini korumaları açısından oldukça büyük önem arz etmektedir. Devlet, sanayi ve finans sektörü birbirlerine ekli çark gibi koordineli çalıştıkları sürece ekonomiye katkı sağlanabilmektedir.

Finans sektöründe özellikle bankacılık ve sigortacılık alanları belirsizlik altında karar verme konusunda oldukça fazla modelleme çalışmalarının yapıldığı geniş bir literatürü kapsamaktadır. Sektör yöneticilerinin ve hisse senedi yatırımcılarının karşısında duran risk faktörleri, kazanç/performans göstergeleri ve durumları tam bir mücadele örneği niteliğindedir. Bazı riskler kontrol edilebildiği halde bazılarını ise yönetmek mümkün olmamaktadır.

Sigortacılık sektöründe faaliyet gösteren ve hisseleri Borsa İstanbul'da işlem gören şirketler, yatırımcılar tarafından oldukça ilgi görmektedir. Şirket bünyesinde, aynı zamanda ülke ve global bazda yaşanan olumlu ya da olumsuz gelişmeler hisse fiyatlarında oynaklık yaratmakta ve yatırımcılar açısından oynaklık, kazanç veya kayıp olarak geri dönmektedir. Hisse senetlerinin fiyatlarında geleceğe dönük tahmin ve beklentiler yatırımcılar için önem sıralamasında ilk sırayı oluşturmaktadır. Türk sigorta sektöründe yer alan ve hisse senetleri Borsa İstanbul'da işlem gören sigorta şirketlerine ait hisse senedi kapanış fiyatlarından oluşan veri seti, günümüz finans ve istatistik alanlarında yaygın kullanım alanına sahip Box Jenkins Yöntemi ile modellenmiş ve geleceğe yönelik fiyat tahminleri yapılmıştır. Tahmin sonuçlarına göre, Box-Jenkins Yöntemi Türkiye sigorta sektörü verilerine uygulandığında doğru sonuçlar vermektedir. Bununla birlikte, bazı ani fiyat değişikliklerinin sebepleri araştırılmalı ve yaşanabilecek ani dalgalanmalar, diğer ekonometrik analizler ile desteklenerek ve risk analizine dahil edilmelidir.

\section{LITERATÜR}

Zaman serileri istatistik, ekonometri ve finans konularının ortak odak noktasını oluşturmaktadır. Bir değişkene ait gözlemlerin eşit zaman aralıklarıyla ölçülmüş değerlerinden zaman serisi oluşmaktadır. Ekonometrik ve istatistiksel yaklaşımlardan farklı olarak bir zaman serisi belirli bir düzene göre kendi geçmiş değerleri tarafindan oluşturulmaktadır. Bu bağlamda Box - Jenkins Yöntemi ekonomi, sağlık, mühendislik, fen ve sosyal bilimler branşlarında, zaman serisi formatındaki verileri analiz ve tahmin etmede sıklıkla başvurulan bir yöntemdir. Literatürde, Box-Jenkins/ARIMA modelinin sigorta sektörüne ilişskin çeşitli araştırmalarda kullanıldığı görülmektedir. Bu araştırmalardan bazıları aşağıda özetlenmiştir.

Bortner, Pulliam ve Yam (2014), ev ve araba poliçeleri için yapılan tahminlerde, ARIMA modelinin, doğrusal regresyon yöntemine göre daha iyi sonuçlar verdiği sonucuna 
ulaşmışlardır. Leng ve Peng (2016), sigorta şirketleri ve emeklilik fonları için yönetilmesi gereken uzun ömür risklerinin ve mortalite oranlarının tahmin edilmesinde yaygın olarak tercih edilen ARIMA modelinin, çalışmanın konusunu oluşturan Lee-Carter modelinde kullanılmakta olduğunu ve Lee-Carter modeli mortalite endeksinin gerçek dinamikleri saptayamadığını belirtmişlerdir. Patrick L.Brockett vd. (1995), doğrusallık varsayımının yeterliğinin testinde kullanılmak üzere geliştirilen istatistiksel testi, sigortaya ilişkin zaman serilerinde uygulamış ve aylık enflasyon, nominal faiz oranı değişkenlerine ait zaman serilerinde doğrusallığı sağlayamadığı sonucuna ulaşılmıştır. ARIMA modellerinin doğrusal olmayan uzantısı olan Bilinear zaman serisi modelinin kullanılabileceği belirlenmiştir. Doğrusal olmayan zaman serileri modellerini, faiz serileri ve enflasyon serileri gibi finansal süreçlere uygulamak için daha fazla bilimsel çalışma yapılmasının gerekliliği vurgulanmıştır. Chen, Cox ve Wang (2010), aylık konut fiyatları endeksine uygulamış oldukları ARIMAGARCH yöntemini kullanarak, Home Equity Conversion Mortgage (HECM) programında yer alan ve prim ödemelerinin doğasında bulunan mortalite ve kıymetten düşme risklerini modellemişlerdir. HECM programı, kurulan modele ve parametre düzenlemesiyle sürdürülebilir hale gelmiştir.

Literatürdeki finansal veriler üzerine yapılan çalışmalar incelendiğinde farklı sonuçların elde edildiği gözlemlenmektedir. $\mathrm{Bu}$ farklılıklar, kullanılan analiz modelinin yapısına ve tarihsel verilerin oynaklığına bağlı olarak ortaya çıkmaktadır. Sigorta sektörüne yatırım yapmak isteyen yatırımcıların yüksek performanslı hisse senetlerini seçmelerine katkı sağlama adına, fiyat hareketlerinin incelenmesi önemli bir göstergedir. Tarihsel verilerin incelenmesi ve analiz edilmesi, iç ve diş etkenler, ekonomik ve siyasi durum, endeksler ve oranlar dikkate alınarak yapılacak yatırımlar, mantıklı yatırımlar olacak, bireysel ve kurumsal olarak da etkili risk yönetiminin temelini oluşturacaktır. Bu çalışmanın amacı, BoxJenkins/ARIMA Yöntemi kullanılarak Borsa İstanbul'da kote sigorta ve bireysel emeklilik şirketlerinin hisse senetlerinin gelecekteki fiyat hareketlerini tahmin etmektir.

\section{VERİ SETİ VE METODOLOJI}

Çalışmada Borsa İstanbul'da işlem gören sekiz sigorta şirketinin hisse senetleri incelenmiş, yeterli sayıda veriye sahip olmayan iki sigorta şirketi veri setine dahil edilmemiştir. Analizde 2 Ocak 2000 ile 30 Nisan 2017 dönemine ait kapanış değerleri kullanılmıştır. Aksigorta A.Ş., Anadolu Hayat Emeklilik A.Ş., Anadolu Anonim Türk Sigorta Şirketi, Güneş Sigorta A.Ş. ve Ray Sigorta A.Ş. 'ye ait hisse senedi fiyatlarının gelecek 1 yıldaki alabileceği değerler araştırmamızda tahmin edilmiştir. Yeterli veri setine sahip olmayan Avisa Emeklilik ve Hayat A.Ş., Halk Sigorta A.Ş. ve payları borsa kotundan çıkarılan Unico Sigorta A.Ş. hisse senedi fiyat verileri analize dahil edilmemiştir.

Çalışmada kullanılan Box-Jenkins/ARIMA yöntemi, yapılandırılmış modelleme temelleri ve kabul edilebilir tahmin performansından dolayı, tek değişkenli yöntemler için bir benchmark tekniği olarak yaygın şekilde kullanım alanına sahip olmaktadır. (Hua ve Pin, 2000: 608) Bu yöntem sayesinde, hem değişkenin gerçekleşen gözlem değerlerinin matematiksel bir kalıbının bulunması ve böylece öngörü yapılması hem de sahte regresyon probleminin üstesinden gelinmesi sağlanmaktadır. ARIMA modelleri aynı zamanda BoxJenkins/ARIMA modelleri olarak da adlandırılmaktadır. (Gürsakal, 2013: 433) BoxJenkins/ARIMA yaklaşımı zaman serilerinin durağan olduğunu varsaymaktadır. 
Kısa dönemli tahminlerde tüm tahmin yöntemleri, orta ve uzun dönemli tahminlerde ise çoklu regresyon, ekonometrik metodlar, çok değişkenli Box-Jenkins/ARIMA yöntemi yaygın olarak kullanılmaktadır. Zaman serisi modellerinden Box-Jenkins/ARIMA yönteminin anlaşılması en zor model olduğu söylenebilmektedir. (O’Donovan, 1983: 7,9) Bunun da sebebi, analiz tekniğine ve uygulama alanına hâkimiyet gerektirmesidir. Box-Jenkins/ARIMA yaklaşımı, uygulamalarda güçlü ve esnek yapısıyla birçok alanda yaygın olarak kullanılmakla birlikte, yaklaşımının en cazip özelliklerinden biri oldukça zengin olası modeller içinden zaman serisi sürecine en uygun modelin bulunabilmesine olanak sağlamasıdır. (Bleikh ve Young, 2014: 17)

Box-Jenkins/ARIMA yönteminde, trend ve mevsimsellik, deterministik veya stokastik ayrımına gidilmeksizin durağanlığı sağlamak için yeteri kadar fark alma işlemi yapılmaktadır. (Akgül, 2003: 104) Zaman serisinin modellenmesi ve tahmin edilmesinde az sayıda parametre kullanılması, geliştirilmiş algoritmaların geniş yazılım programları yardımıyla çözümlenebilmesi sayesinde büyük gözlem kümeleri ile çalışmayı mümkün kılmaktadır. Yöntem, zaman serilerini tarihsel veriler temelinde bir modelle mevcut zaman serilerini açıklamaktadır. Minimum 50 gözlem ve verilerin günlük, haftalık, aylık veya 3 aylık periyotlarda olması gerekmektedir. Kararlı bir zaman serisinde, olasılık dağılımı zaman içinde değişmediği, stokastik bir süreç olduğu tanımlanmaktadır. Uygulamada zaman serileri zayıf istikrarlı olmaktadır ki, tüm gözlemler için ortalama değer ve dağılım sabitse kovaryans sadece zaman kaydırma fonksiyonu olmaktadır. (Mećiarová, 2007: 73,74)

Box-Jenkins/ARIMA yöntemi, zaman serisinin mevsimsel etki taşıyıp taşımamasına göre farklılık göstermektedir. Model tanımlanmadan önce zaman serisi değerlerinin $\left(y_{1}, y_{2}, \ldots, y_{n}\right)$ ortalama ve varyansı zaman içinde sabit ve seri durağan olmalıdır. Sabit ortalama ve varyans, otokorelasyonlu yapının ortadan kaldırılmasıyla elde edilmektedir. Orijinal zaman serisi değerleri durağan değilse ve mevsimsel etki içermiyorsa, birinci ya da ikinci fark alma işlemi, durağanlığın sağlanmasında genellikle yeterli olmaktadır. Orijinal zaman serisi değerleri durağan değilse ve mevsimsel etki içeriyorsa, daha farklı kompleks dönüşümlere ihtiyaç duyulmaktadır. (Ngo, 2013: 1,3)

Zaman serisi modelleri bir değişkenin kendi geçmiş değerlerindeki bilgileri kullanarak varsayımsal bir açıklama sürecini dikkate alarak aynı değişkenin gelecekte alabileceği değerleri ön raporlamaya çalışmaktadır. (Sevütekin ve Nargeleçekenler, 2010: 138) Birçok süreç $A R(p)$ ve $M A(q)$ süreçlerinin ikisini de içerecek şekilde hem gecikmeli gözlem değerleri ile hem de gecikmeli hata terimleri dizisi şeklinde tanımlanmaktadır. (Schmidt, 2011: 168)

Zaman serilerinin en önemli türü durağan zaman serileridir. Bir zaman serisinin özellikleri zaman kökenli bir değişiklikten etkilenmiyorsa tam durağandır. Başka bir deyişle, gözlemlerin ortak olasılık dağılımı $\left(y_{t}, y_{t+1}, \ldots, y_{t+n}\right), \quad\left(y_{t+k}, y_{t+k+1}, \ldots, y_{t+k+n}\right)$ gözlemlerinin ortak olasılık dağılımı ile birebir aynıdır. Durağanlık bir tür istatistiksel denge ya da verilerin kararlı olmasidır. (Montgomery vd., 2008: 25) Herhangi bir zaman serisi, stokastik yada rassal süreç ile ortaya çıkmış olabilir. Bu zaman serisi verileri bir örnek gibi işlem görmektedir. Ana süreçte ise bir dönem için gerçekleşmiş bir durumdur. İstatistiksel anlamda durağanlık, stokastik bir $Y_{t}$ sürecinin sabit bir aritmetik ortalama $\left(E\left(Y_{t}\right)=\mu\right)$ etrafında dağılması, sabit varyans $\left(\operatorname{Var}\left(Y_{t}\right)=E\left(Y_{t}-\mu\right)^{2}=\sigma^{2}\right)$ ve gecikme mesafesine bağlı kovaryansa $\left(\gamma_{k}=E\left[\left(Y_{t}-\mu\right)\left(Y_{t-k}-\mu\right)\right]\right)$ sahip olmasıdır. (Ertek, 1996: 380) 
G. P. E. Box ile G. M. Jenkins’in Time Series Analysis: Forecasting and Control kitabının yayımlanması yeni bir kestirim araçları kuşağının yolunu açmıştır. Yaygın adıyla Box-Jenkins/ARIMA Yöntemi denen bu yeni kestirim yöntemleri, tek denklem ya da eşanlı denklem modellerinin değil, iktisadi zaman serilerinin olasılık özelliklerini, "bırakın da veriler konuşsun" felsefesiyle çözümlemeyi vurgulamaktadır. $Y_{t}$ 'yi k tane açıklayıcı değişken $X_{1}, X_{2}, X_{3}, \ldots, X_{k}$ ile açıklayabilen regresyon modellerinin tersine, Box-Jenkins/ARIMA türü zaman serisi modellerinde $Y_{t}$, Y'nin kendi eski yada gecikmeli değerleri ve olasılıklı hata terimleriyle açıklanmaktaydı. (Gujarati, 2010: 735) ARIMA (p,d,q) modelinin genel gösterimi aşağıdaki şekilde olmaktadır:

$$
\left(1-\varphi_{1} B-\varphi_{2} B^{2}-\cdots-\varphi_{p} B^{p}\right)(1-B)^{d_{z_{t}}}=\left(1-\theta_{1} B-\theta_{2} B^{2}-\cdots-\theta_{q} B^{q}\right) \alpha_{t}
$$

Yukarıdaki eşitlikte $z_{t}$, sabit varyanslı bir dönüştüren $\left(\bar{z}_{t}=z_{t}-\mu\right), z_{t}$, seçilen bir $d$ değeri ile fark belirleme operatörü $(1-B)^{d}$ ile çarpılmaktadır. Uygun değerleri temsil eden $p$ ve $\mathrm{q}$ değişkenleri ile $\left(1-\varphi_{1} B-\varphi_{2} B^{2}-\cdots-\varphi_{p} B^{p}\right)$, AR operatörü, $\left(1-\theta_{1} B-\theta_{2} B^{2}-\cdots-\theta_{q} B^{q}\right)$ ise MA operatörüdür. (Pankratz, 1983: 116)

Durağan olmayan zaman serileri için bütünlenen ARMA modelleri olarak tanımlanan $\operatorname{ARIMA}(p, d, q)$ modellerini kurarken ilk basamak işlem otoregresif terim sayısı "p", gecikmeli hata terimi sayısı "q" ve homojenlik mertebesi olan "d" katsayılarının belirlenmesidir. "d" katsayısı belirlenirken uygulamalarda çoğunlukla bir ya da iki kez fark alınması durağanlığın sağlanmasında yeterli olduğundan $d=1$ veya $d=2$ olarak belirlenmektedir. Daha sonrasında belirlenecek olan "p" ve "q" katsayılarında, serinin zaman grafiğine bakılmakta ve serinin otokorelasyon fonksiyonu ve kısmi otokorelasyon fonksiyonundan yararlanılmaktadır. Serinin dönüşümü sonrasında $\operatorname{ARMA}(p, q)$ sürecinin MA kısmı için otokorelasyon fonksiyonundan, AR kısmı için kısmi otokorelasyon fonksiyonundan yararlanılmaktadır. (Akgül, 2003: 111) $A R(p)$ ve MA(q) süreçlerindeki " $p$ " ve "q" değerlerinin tahmin edilmesinde korelogram analizinden yararlanılmaktadır.

Korelogram oluşturulurken zaman serisi gözlemleri arasındaki bağımlılığı göstermek üzere örneklem otokorelasyon fonksiyonu (ACF) ve bir zaman serisi değişkeni ile herhangi bir gecikmeli değeri arasındaki korelasyonu belirlemek amacıyla, diğer tüm gecikmeli değerlerin etkilerinin dişlanmasıyla bulunan kısmi otokorelasyon fonksiyonu (PACF) kullanılmaktadır. (Lindsay, 2004: 214)

Box - Jenkins yaklaşımına göre, stokastik bir süreci modellemede aşağıdaki adımlar izlenmektedir: (Grene, 2008: 727)

- $\quad$ Birinci Adım: Durağan seri elde etmek üzere veri seti dönüştürülmektedir. Bu dönüşüm birinci farkların alınması ve logaritmasının alınması ya da otokorelasyon fonksiyonu üstel azalma gösteriyorsa her iki dönüşüm birlikte kullanılmaktadır.

- İkinci Adım: Elde edilen ARMA modelinin parametreleri (genellikle) lineer olmayan en küçük kareler yöntemi ile tahmin edilmektedir.

- $\quad$ Üçüncü Adım: Tahmin edilen modelden elde edilen artıklar üretilmekte ve beyaz gürültü serisine benzerlik olup olmadığı doğrulanmaktadır. Doğrulama yapılamıyorsa modeli belirlemek için ikinci adıma geri dönülmektedir.

- Dördüncü Adım: Model artık tahmin amacıyla kullanılmaktadır. 
Yukarıda bahsedilen ve dört aşamadan oluşan adımların uygulanması aynı zamanda Box-Jenkins/ARIMA metodolojisi kullanılarak uygun ARIMA(p,d,q) modelinin tahmin edilmesidir.

ARIMA modelinin kullanılabilmesi için veri setinin grafiğinin incelenmesi, gerekli veri dönüşümlerinin yapılması, modeldeki bağımlılıkların belirlenmesi, parametre tahminleri, tanılama ve modelin seçilmesi gerekmektedir. Herhangi bir veri analizinde ilk basamak olarak, veri setinin zaman yolu grafiğinin oluşturulması, potansiyel anormallikleri belirlemede oldukça faydalı olmaktadır. Veri setindeki değişkenlik zamanla artıyorsa, varyansı stabilize etmek için veri dönüşümü yapmak gerekmektedir. (Shumway ve Stoffer, 2006: 143)

\section{ANALIZ VE BULGULAR}

Çalışmada zaman serilerinin durağanlıklarının analiz edilebilmesi için, öncelikle veri setlerinin zaman yolu grafiği incelenmiştir. Yatay eksende zaman değişkeni yer alırken, dikey eksende hisse senedinin 17 yıl boyunca aldığ 1 fiyat değeri TL cinsinden yer almaktadır. Görsel olarak fark edilebilen trend ya da sapan değerlerin varlığı, durağanlığ 1 ve devamında serinin dağılımını bozmaktadır. Seriler görsel olarak incelendiğinde ham verilerin durağan olmadığı görülmektedir. Serilerin birinci farkları alındığında sıfır etrafında dağılım gösterdikleri belirlenmiştir. Analiz aşamasında sonuçların sapan değerlerden etkilenmemesi için fark serilerinde aşırı büyük ve aşırı küçük değerler veri setinden çıkarılmıştır. Başka bir deyişle ani kırılmalar sonucu ortaya çıkan günlük kapanış değeri fiyatları analize dahil edilmemiştir. Analiz edilen toplam beş sigorta şirketinin günlük hisse senedi kapanış fiyatı verilerinden oluşan zaman yolu grafikleri, birinci farkları alınmış serilerin grafikleri ve serilere ait tanımlayıcı istatistikler aşağıdaki şekillerde gösterilmiştir:

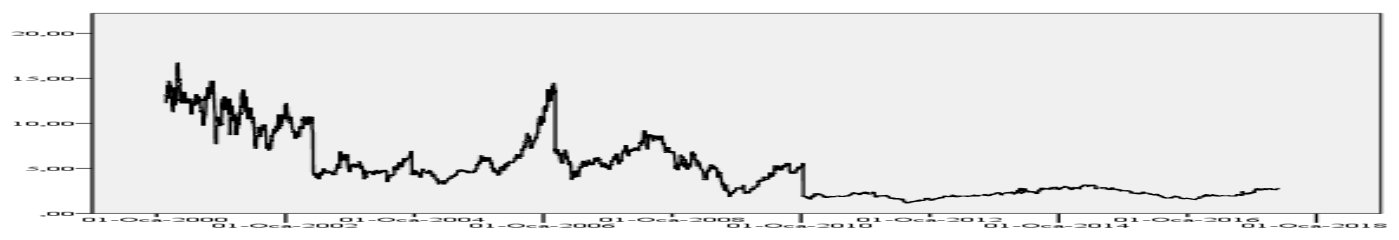

Grafik 1. Aksigorta A.Ş. 2000 Ocak-2017 Mayıs Yılları Arası Günlük Hisse Senedi Kapanış Fiyatları (TL)

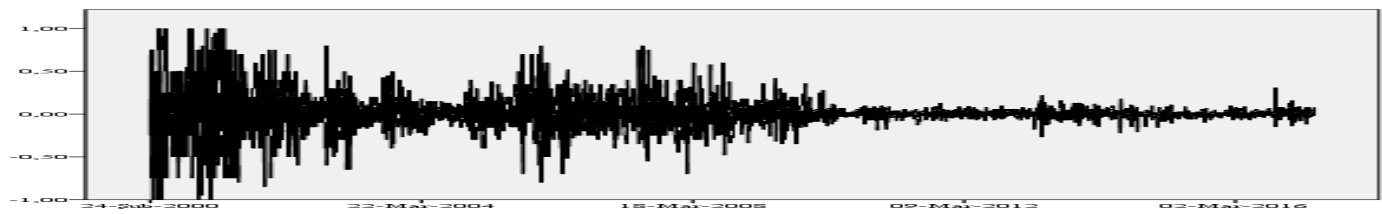

Grafik 2. Aksigorta A.Ş. 2000 Ocak- 2017 Mayıs Yılları Arası Günlük Hisse Senedi Kapanış Fiyatları Birinci Fark Değerleri Dağılımı 


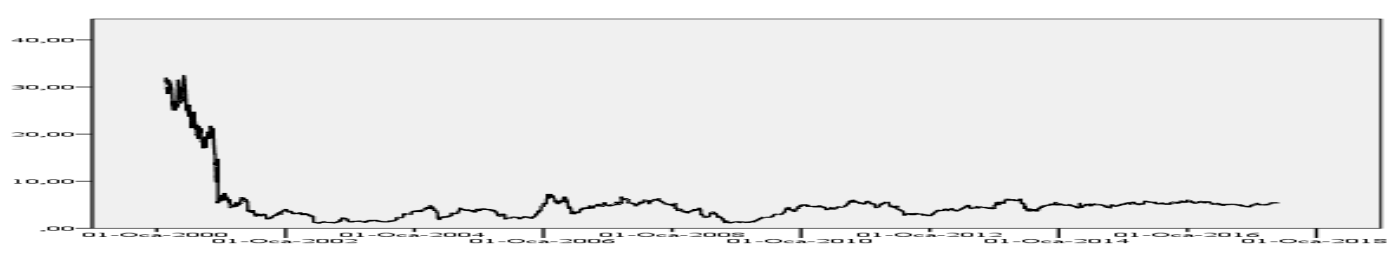

Grafik 3.Anadolu Hayat Emeklilik A.Ş. 2000 Ocak- 2017 Mayıs Yılları Arası Günlük Hisse Senedi Kapanış Fiyatları (TL)

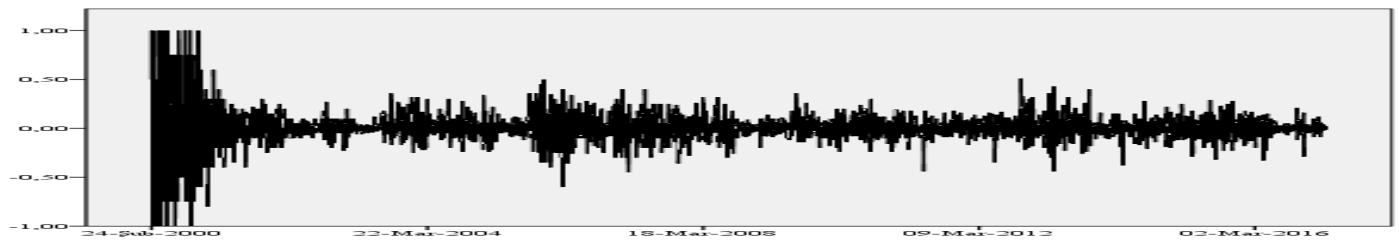

Grafik 4. Anadolu Hayat Emeklilik A.Ş. 2000 Ocak- 2017 Mayıs Yı1ları Arası Günlük Hisse Senedi Kapanış Fiyatları Birinci Fark Değerleri Dağılımı

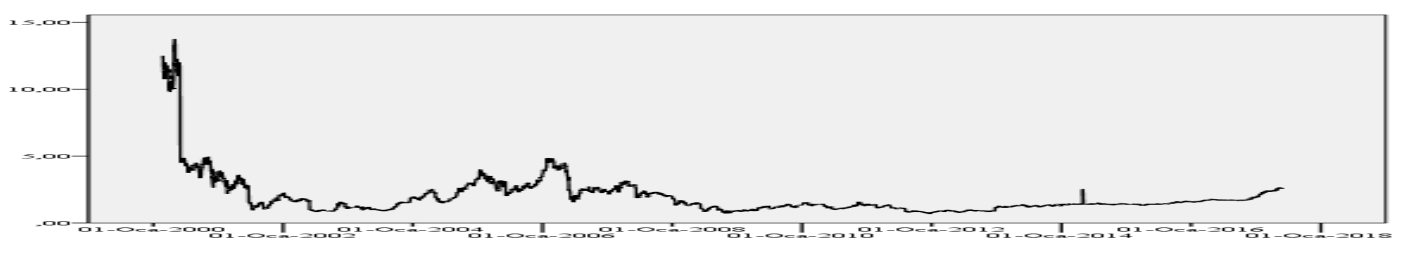

Grafik 5. Anadolu Anonim Türk Sigorta Şirketi 2000 Ocak- 2017 Mayıs Y1lları Arası Günlük Hisse Senedi Kapanış Fiyatları (TL)

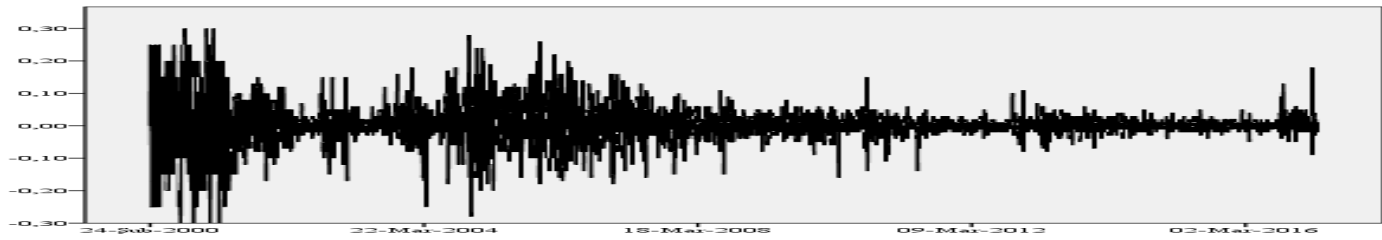

Grafik 6. Anadolu Anonim Türk Sigorta Şirketi 2000 Ocak- 2017 Mayıs Y1lları Arası Günlük Hisse Senedi Kapanış Fiyatları Birinci Fark Değerleri Dağılımı

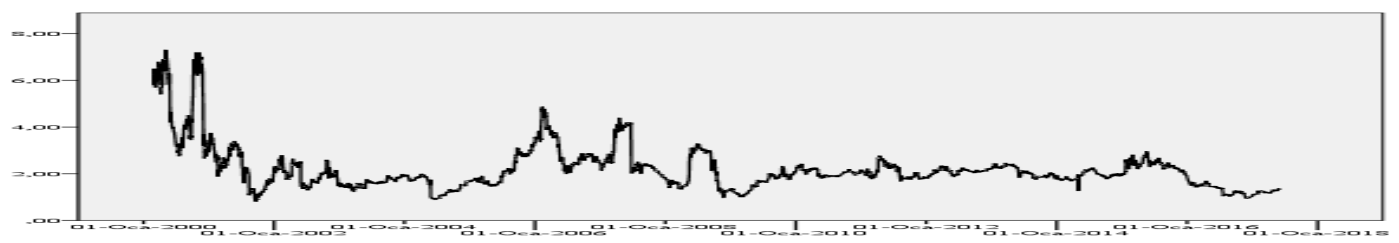

Grafik 7. Güneş Sigorta A.Ş. Ocak- 2017 Mayıs Yılları Arası Günlük Hisse Senedi Kapanış Fiyatları (TL) 


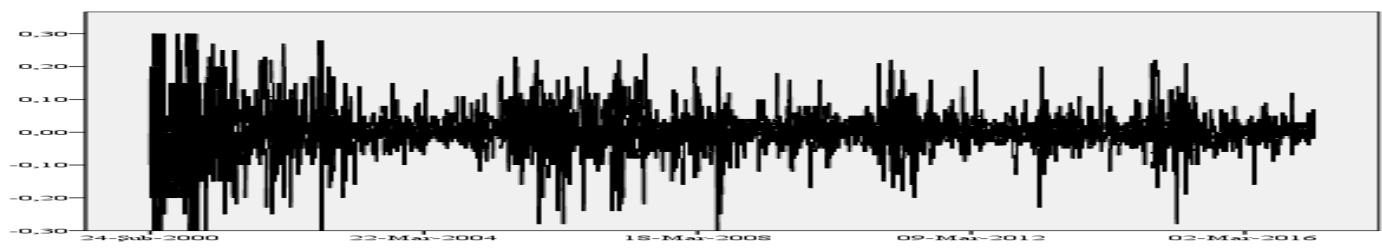

Grafik 8. Güneş Sigorta A.Ş. Ocak-2017 Mayıs Yılları Arası Günlük Hisse Senedi Kapanış Fiyatları Birinci Fark Değerleri Dağılımı

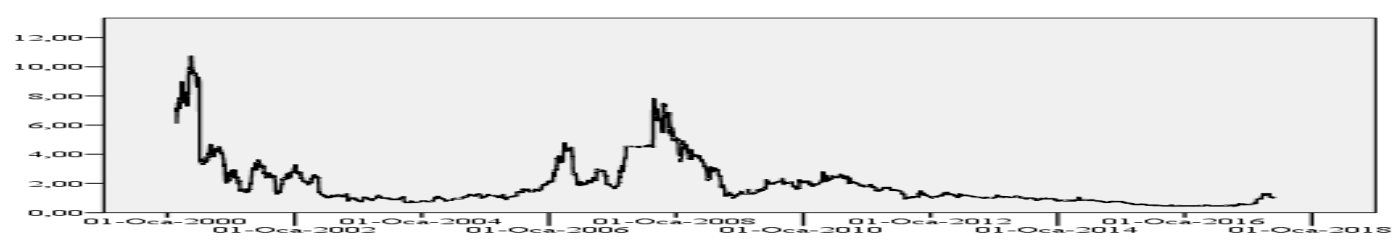

Grafik 9. Ray Sigorta A.Ş. Ocak-2017 Mayıs Yılları Arası Günlük Hisse Senedi Kapanış Fiyatları (TL)

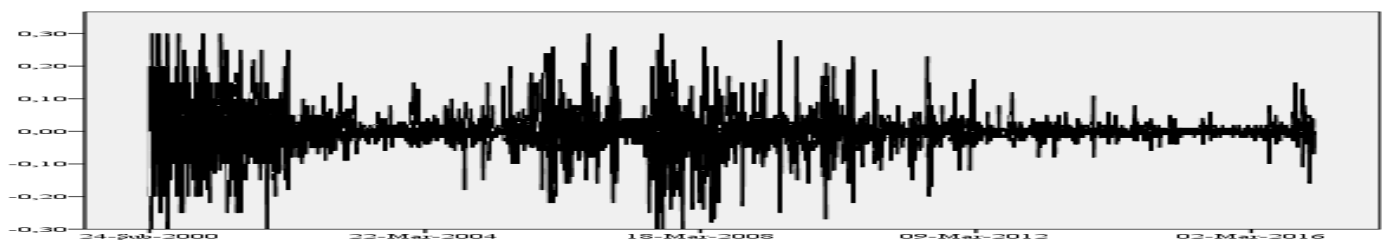

Grafik 10. Ray Sigorta A.Ș. Ocak- 2017 Mayıs Yılları Arası Günlük Hisse Senedi Kapanış Fiyatları Birinci Fark Değerleri Dağılımı

Zaman serilerin durağanlıklarının test edilmesinde $\mathrm{AR}(1)$ ve $\mathrm{AR}(2)$ modellerinin katsayıları açıklayıcı niteliktedir. Başka bir deyişle birinci ve ikinci mertebeden otoregresif seriler oluşturularak katsayı tahminlerinin anlamlılıkları test edilmiştir.

$\mathrm{AR}(1)$ ve $\mathrm{AR}(2)$ denklemlerinde yer alan katsayı tahminleri incelendiğinde, tüm süreçteki katsayıların; (Box ve Jenkins, 1976: 58)

AR(1) denkleminde yer alan $\alpha_{1}$ katsayısının $-1<\alpha_{1}<1$ koşulunu,

AR(2) denkleminde yer alan $\alpha_{1}$ ve $\alpha_{2}$ katsayılarının da

$$
\begin{aligned}
& \alpha_{2}+\alpha_{1}<1, \\
& \alpha_{2}-\alpha_{1}<1, \\
& -1<\alpha_{2}<1,
\end{aligned}
$$

Koşullarını birlikte sağladıklarından dolayı birinci farkları alınan serilerin hepsinin durağan olduğu sonucuna ulaşabiliriz. Birinci farkları alınan zaman serisi verileri 
incelendiğinde her bir serinin ortalamada durağan oldukları görülebilmektedir. Ortalama sıfır bandında saçılım göstermektedirler. AKGRT, ANHYT, ANSGR, GUSGR ve RAYSG için oluşturulan otoregresif sürecin denklemleri Tablo 1'de, hesaplanan parametre değerleri ile oluşturulan otoregresif sürecin denklemleri ise Tablo 2'de yer almaktadır.

Tablo 1. Sigorta Şirketlerinin AR(1) ve AR(2) Denklemleri

\begin{tabular}{|c|c|}
\hline ŞirketKodu & AR(1) ve AR(2) Süreç Tahmin Parametreleri \\
\hline \multirow[t]{2}{*}{ AKGRT } & $\operatorname{AR}(1): \mathrm{AKGRT}_{\mathrm{t}}=\mathrm{m}+\alpha_{1} \mathrm{AKGRT}_{\mathrm{t}-1}+\varepsilon_{\mathrm{t}}$ \\
\hline & 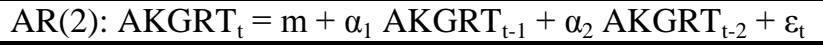 \\
\hline \multirow[t]{2}{*}{ ANHYT } & AR(1): $\operatorname{ANHYT}_{t}=m+\alpha_{1}$ ANHYT $_{t-1}+\varepsilon_{t}$ \\
\hline & $\operatorname{AR}(2): \mathrm{ANHYT}_{\mathrm{t}}=\mathrm{m}+\alpha_{1} \mathrm{ANHYT}_{\mathrm{t}-1}+\alpha_{2} \mathrm{ANHYT}_{\mathrm{t}-2}+\varepsilon_{\mathrm{t}}$ \\
\hline \multirow[t]{2}{*}{ ANSGR } & AR(1): $\operatorname{ANSGR}_{\mathrm{t}}=\mathrm{m}+\alpha_{1} \mathrm{ANSGR}_{\mathrm{t}-1}+\varepsilon_{\mathrm{t}}$ \\
\hline & AR(2): $\operatorname{ANSGR}_{t}=m+\alpha_{1} \operatorname{ANSGR}_{t-1}+\alpha_{2} \operatorname{ANSGR}_{t-2}+\varepsilon_{t}$ \\
\hline \multirow[t]{2}{*}{ GUSGR } & AR(1): GUSGR $_{t}=m+\alpha_{1}$ GUSGR $_{t-1}+\varepsilon_{t}$ \\
\hline & AR(2): GUSGR $_{t}=m+\alpha_{1}$ GUSGR $_{t-1}+\alpha_{2}$ GUSGR $_{t-2}+\varepsilon_{t}$ \\
\hline \multirow[t]{2}{*}{ RAYSG } & AR(1): RAYSG $_{t}=m+\alpha_{1}$ RAYSG $_{t-1}+\varepsilon_{t}$ \\
\hline & AR(2): RAYSG $_{t}=m+\alpha_{1}$ RAYSG $_{t-1}+\alpha_{2}$ RAYSG $_{t-2}+\varepsilon_{t}$ \\
\hline
\end{tabular}

Her bir sigorta şirketi için AR(1) ve AR(2) oluşturulmuş ve devamında denklemlerin En Küçük Kareler Yöntemi (EKK) ile tahmin edilmesi sonucunda sonuçlar şu şekilde elde edilmiştir:

Tablo 2. Sigorta Şirketlerinin AR(1) ve AR(2) Denklemlerinin Katsayı Tahminleri

\begin{tabular}{|c|c|}
\hline Şirket Kodu & AR(1) ve AR(2) Süreç Tahmin Parametreleri \\
\hline AKGRT & $\begin{array}{l}\text { AR(1): } \text { AKGRT }_{t}=-0,0024+\alpha_{1} 0,0039_{t-1}+\varepsilon_{t} \\
\text { AR(2): } \text { AKGRT }_{t}=-0,0023+\alpha_{1} 0,0050_{t-1}-\alpha_{2} 0,0105_{t-2}+\varepsilon_{t}\end{array}$ \\
\hline ANHYT & $\begin{array}{l}\text { AR(1): } \text { ANHYT }_{t}=-0,0062-\alpha_{1} 0,0074_{t-1}+\varepsilon_{t} \\
\text { ANHYT }_{t}=-0,0059+\alpha_{1} 0,0003_{t-1}-\alpha_{2} 0,0628_{t-2}+\varepsilon_{t}\end{array}$ \\
\hline ANSGR & $\begin{array}{l}\text { AR(1): } \text { ANSGR }_{\mathrm{t}}=-0,0021+\alpha_{1} 0,0283_{\mathrm{t}-1}+\varepsilon_{\mathrm{t}} \\
\text { AR(2): } \text { ANSGR }_{\mathrm{t}}=-0,0018+\alpha_{1} 0,02225_{\mathrm{t}-1}+\alpha_{2} 0,0406_{\mathrm{t}-2}+\varepsilon_{\mathrm{t}}\end{array}$ \\
\hline GUSGR & $\begin{array}{l}\text { AR(1): } \text { GUSGR }_{\mathrm{t}}=-0,0010+\alpha_{1} 0,0666_{\mathrm{t}-1}+\varepsilon_{\mathrm{t}} \\
\text { AR(2): GUSGR } \\
\text { G }=-0,0010+\alpha_{1} 0,0670_{\mathrm{t}-1}+\alpha_{2} 0,0180_{\mathrm{t}-2}+\varepsilon_{\mathrm{t}}\end{array}$ \\
\hline RAYSG & $\begin{array}{l}\text { AR(1): } \text { RAYSG }_{t}=-0,0013+\alpha_{1} 0,0720_{\mathrm{t}-1}+\varepsilon_{\mathrm{t}} \\
\text { AR(2): } \text { RAYSG }_{\mathrm{t}}=-0,0013+\alpha_{1} 0,0732_{\mathrm{t}-1}-\alpha_{2} 0,0407_{\mathrm{t}-2}+\varepsilon_{\mathrm{t}}\end{array}$ \\
\hline
\end{tabular}

Box-Jenkins/ARIMA/ARIMA modelini kurarken, modelin görsel olarak tanımlanmasında korelogram kullanılmaktadır. Serilerin durağanlık durumları kontrol edildikten sonra, serideki elemanların rassal olup olmadığ Otokorelasyon fonksiyonunun grafiği olan korelogram bu aşamada test edilmektedir. Seri elemanları rassal dağılım gösteriyorsa, ACF değerlerinin dağılımı sıfır etrafında olacaktır. Seride trend, mevsimsellik, konjonktürel etkiler varsa, ya da seri elemanları arasında otokorelasyon mevcutsa korelogram grafiğinden görülebilmektedir. Eğer bu etkiler giderilmezse analiz sonuçları hatalı çıkmaktadır. Korelogram, geometrik olarak azalıyor ise AR(1) modeli önerilmektedir. Ancak AR(2) ve bir üst modeller de aday modeller olarak test edilmelidir. Eğer ilk korelasyon değeri anlamlı (bu durumda seri terimleri arasında korelasyon vardır) ve seri yine geometrik olarak azaliyorsa, $\operatorname{ARMA}(1,1)$ önerilmektedir. Korelogram sönümlü bir sinüs dalgası şeklindeyse $\mathrm{AR}(2)$ ve daha üst modellerin anlamlılıkları test 
edilmelidir. Korelogramdaki PACF değerleri, AR sürecinin belirlenmesinde kullanılmaktadır. (Kennedy, 2003: 341,342)

Grafik 11, Grafik 12, Grafik 13, Grafik 14 ve Grafik 15'de her bir sigorta şirketine ait korelogramlarda yer alan otokorelasyon (ACF) ve kısmi otokorelasyon (PACF) değerleri dikey eksende birlikte yer almaktadır. Çizgi grafiklerinden mavi renkli ACF, yeşil rekli PACF değerlerini göstermektedir. Yatay eksende ise gecikme sayıları yer almaktadır.

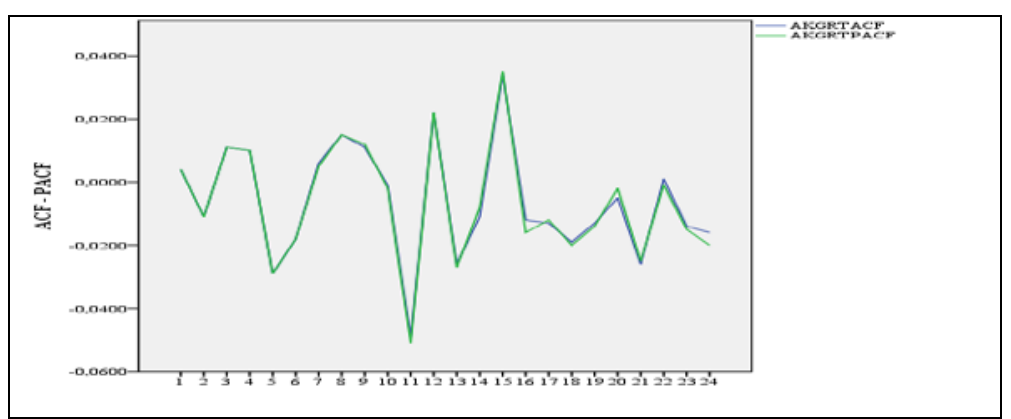

Grafik 11. Aksigorta A.Ş. Otokorelasyon (ACF) ve Kısmi Otokorelasyon (PACF) Grafikleri

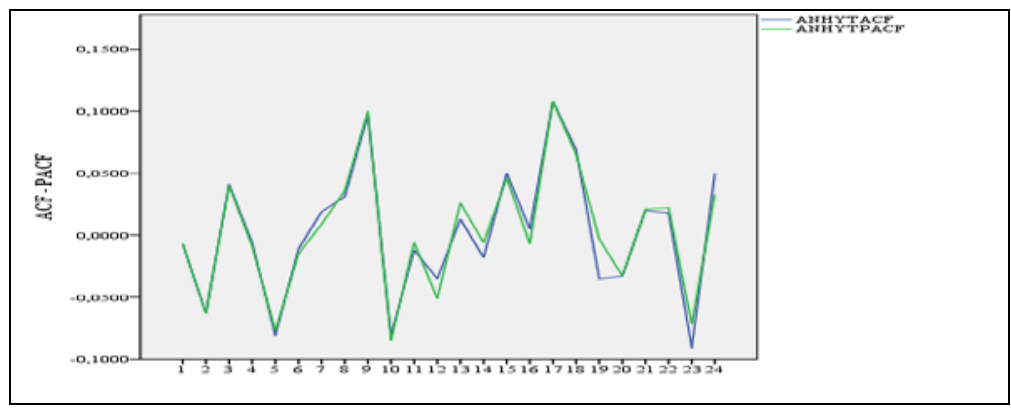

Grafik 12. Anadolu Hayat Emeklilik A.Ş. Otokorelasyon (ACF) ve Kısmi Otokorelasyon (PACF) Grafikleri

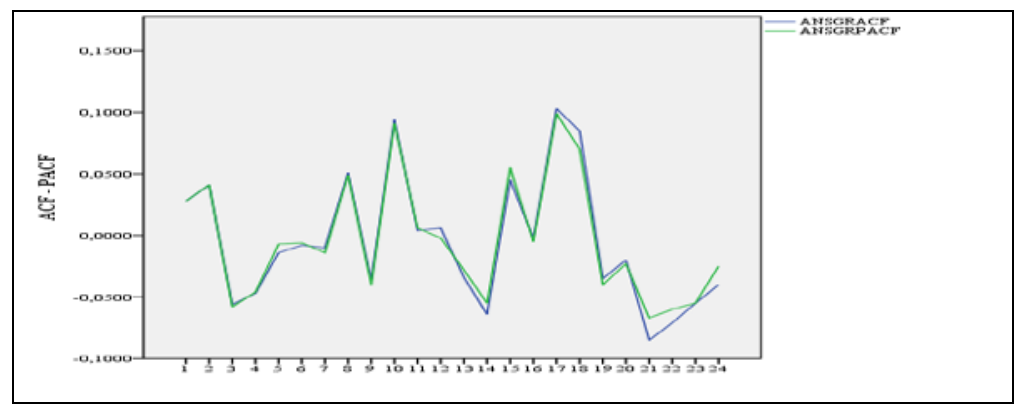

Grafik 13. Anadolu Anonim Türk Sigorta Şirketi Otokorelasyon (ACF) ve Kısmi Otokorelasyon (PACF) Grafikleri 


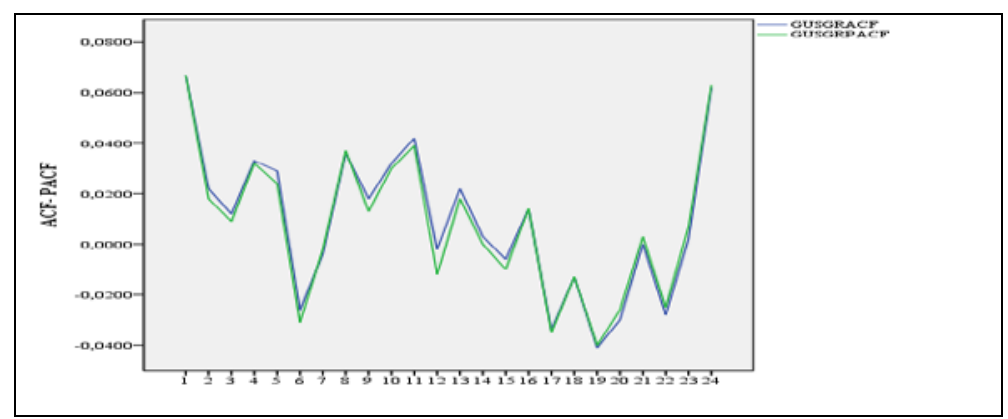

Grafik 14. Güneş Sigorta A.Ş. Otokorelasyon (ACF) ve Kısmi Otokorelasyon (PACF) Grafikleri

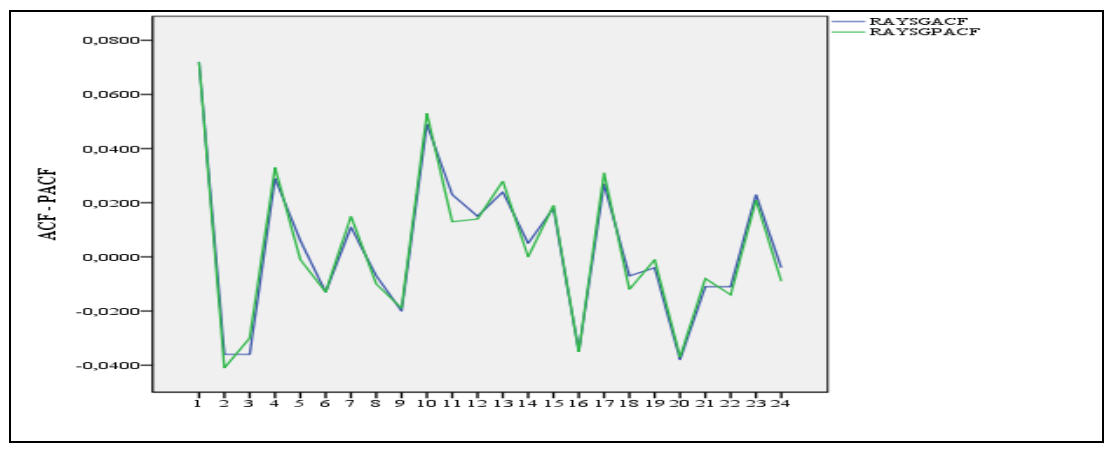

Grafik 15. Ray Sigorta A.Ş. Otokorelasyon (ACF) ve Kısmi Otokorelasyon (PACF) Grafikleri

Yukarıdaki grafiklerde yatay eksen gecikme sayısını göstermektedir. Burada gecikme sayısı veri sayısına ve veri yapısına uygun olarak belirlenmektedir. Hisse senedinin gün içinde aldığı en son fiyat değeri, o senedin kapanış fiyatıdır. Bugünün kapanış fiyatı, yarının açılış fiyatı olarak ardışık devam etmektedir. Dolayısıyla borsa fiyat değerleri arasında otokorelasyon mevcuttur. Bu otokorelasyonu ya da seri bağıntıyı ortadan kaldırmak amacıyla gecikme işlemi uygulanır. Buradaki asıl amaç serinin geçmişe yönelik davranışlarında periyodik hareketler ya da benzer kalıplar olup olmadığının analizidir. Bu çalışmada gecikme sayıs1 30 olarak alınmış ve gecikme sayısı artırıldığında otokorelasyon değerlerinin azaldığ1 gözlemlenmiştir. Gecikme işlemi ile bağımlı değişkeni doğrudan etkileyebilecek tarihi faktörler kontrol edilebilmektedir. Geciktirilmiş veriler, günlük hisse senedi fiyatının, bir önceki günün hisse senedi fiyatı ile karşılaştırılması şeklinde olmaktadır. Devamında yapılan fark alma işlemi ile seri terimler arasındaki bağlantı, elde edilen yeni seri ile ortadan kaldırılmıştır.

Belirleme aşamasından sonra tahmin aşamasına geçilmektedir. Bu aşamada eldeki verilere dayanarak ve inisiyatif kullanılarak aday modeller belirlenmektedir. Aday modellerin her biriyle kurulan ARIMA(p,d,q) modellerinin değerlendirmesi yapılmaktadır. Bir ya da birkaç farklı model veri yapısına uygun modeller olarak belirlenebilir. Sonrasında ise bazı 
ayırt edici kriterler dikkate alınarak ayırt edici kontrol yapılır ve seçilen model kullanılarak öngörüler yapılmaktadır.

$\mathrm{Bu}$ çalışmada test edilen ARIMA modelleri; $\operatorname{ARIMA}(1,0,1), \operatorname{ARIMA}(1,0,2)$, ARIMA(2,0,1), $\quad \operatorname{ARIMA}(2,0,2), \quad \operatorname{ARIMA}(0,1,1), \quad \operatorname{ARIMA}(0,1,0), \quad \operatorname{ARIMA}(1,1,0)$, ARIMA(1,1,1), ARIMA(1,1,2), $\quad \operatorname{ARIMA}(2,1,0), \quad \operatorname{ARIMA}(0,1,2), \quad \operatorname{ARIMA}(1,1,2)$, ARIMA(2,1,1), $\quad \operatorname{ARIMA}(2,1,2), \quad \operatorname{ARIMA}(1,2,1), \quad \operatorname{ARIMA}(1,2,2), \quad \operatorname{ARIMA}(2,2,1) \quad$ ve $\operatorname{ARIMA}(2,2,2)$ olarak belirlenmiş ve test edilmiştir. Hisse senetleri kapanış fiyatlarına ait zaman serileri, birinci fark işlemi uygulandığında durağanlaştığından d'si 1 (bir) olan modeller arasından, seriyi en iyi açıklayan ARIMA modeli, Tablo 3'de karşıllaştırılmıştır.

İstatistiksel modellerin performanslarını karşılaştırmak için modelleri tahmin verileri üzerinde değerlendirmek gerekmektedir. Performans kriterleri olarak adlandırılan bir takım hesaplamalar sonucunda elde edilen sayısal değerler ile modellerin karşılaştırılması yapılmaktadır. Veri seti doğasına en uygun şekilde uyum sağlayan model, veri setinin özelliklerini en iyi açıklayabilen model olmaktadır. Karşılaştırılmak istenen tahmin modellerinin doğruluk derecesini saptamak için MAPE (Mean Absolute Percentage Error), RMSE (Root Mean Square Error) MAE (Mean Absolute Error) kriterleri kullanılmaktadır. MAPE ve RMSE performans kriterlerinin esasını oluşturmaktadırlar. MAE ise MAPE ve RMSE'nin tamamlayıcısı olarak kabul edilmektedir. (Stanković vd., 2017: 47) Hesaplanan MAE ise MAPE ve RMSE değerlerinin küçük olması, beklenen değer ile fiili değerin birbirine yakın olmasının ifadesidir. Bu performans kriterleri aşağıdaki formülasyonlar ile tanımlanmaktadır: (Panagopoulos vd., 2012: 985)

$$
\begin{aligned}
& M A P E=\frac{1}{n} \sum_{i=1}^{n}\left|\frac{F_{i}-A_{i}}{A_{i}}\right| \times 100 \\
& M A E=\frac{1}{n} \sum_{i=1}^{n}\left|F_{i}-A_{i}\right|
\end{aligned}
$$

Modelde hesaplanan RMSE değeri, modeldeki hataların toplamını göstermektedir. Genellikle RMSE değeri serbestlik derecesine bölündügünde 1 değerinden küçük ise üzerinde çalışılan model iyi çalışan bir model anlamına gelmektedir. Varsayımsal olarak $\left(e_{i}, i=\right.$ $1,2, \ldots, n)$ olarak hesaplanan ve $\mathrm{n}$ tane örneklemden elde edilen model hatası $e$, örneklem hatas 1 olarak adlandırılmakta ve yansız bir tahminci olmaktadır. Veri seti için hesaplanan RMSE değeri aşağıdaki şekilde hesaplanmaktadır: (Chai ve Draxler, 2014: 1248)

$$
\text { RMSE }=\sqrt{\frac{1}{n} \sum_{i=1}^{n} e_{i}^{2}}
$$

Bir diğer kriter Bayesian Information Criteria (BIC) değeridir. Schwarz bilgi kriteri olarak da adlandırılmaktadır. Farklı parametre sayılarına sahip bir dizi model arasından seçim yapmak durumunda kalındığında, modeldeki parametrelerin sayısı arttıkça çalışılan veri setinin en çok olabilirliği (likelihood) de artmaktadır. Bu durum, modele daha fazla değişken eklendiğinde kalemize atılan penaltılara benzetilebilir. $X$ veri kümesi olarak tanımlandığında $\left(X_{1}, X_{2}, \ldots, X_{n}\right)$, istenen parametrik model adayları $\mathrm{M}\left(M_{1}, M_{2}, \ldots, M_{k}\right)$, model adayları 
arasından, aşağıdaki formül yardımıyla kıyaslama yapmak mümkün olmaktadır; (Schwarz, 1978: 461)

$$
\log M_{j}\left(X_{1}, \ldots, X_{n}\right)-\frac{1}{2} k_{j} \log n
$$

$\mathrm{Bu}$ formül, farklı i ve j değerleri için bir veri kümesi oluşturmaktadır. Bu veri kümesi bir aralık şeklinde tanımlandığından, bu aralık ne kadar geniş olursa doğru modele ulaşma olasılığı o kadar yüksek olmaktadır. Başka bir deyişle, uygun modeli ararken, deneme yanılma yoluyla eldeki fonksiyona değer vererek, her bir değer için fonksiyonun hesapladığ sonuçlar, bir küme oluşturmakta ve bu kümeye de aralık adı verilmektedir. Hesaplanan BIC değerinin sıfırdan küçük ya da büyük olması önemli olmaktadır. BIC değeri (eksi işaretli olarak) ne kadar küçükse, aday modelin veriye uyumu o kadar iyi olmaktadır. (Duyar, 1995: 103)

Bu çalışmada, hisse senetlerinin gelecekte alabileceği değerleri tahmin etmek üzere bir modele ihtiyaç duyulmaktadır. Fakat model bilinmediğinden, deneme yanılma yoluyla yaklaşım yapmak gerekmektedir. $\mathrm{Bu}$ yaklaşımlar da yukarıda yapılan aday modeller arasından, veri setini en iyi açıklayan aday modelleri kıyaslayarak analiz edilmiştir. Birbiriyle kıyaslanarak ve deneme-yanılma yoluyla, sigorta şirketlerinin tarihsel hisse senedi fiyat serileri davranışlarına en iyi uyum göstereceği düşünülen aday modeller, $\operatorname{ARIMA}(0,1,0)$, ARIMA(0,1,1), ARIMA(1,1,0), $\quad \operatorname{ARIMA}(1,1,1), \quad \operatorname{ARIMA}(1,1,2), \quad \operatorname{ARIMA}(2,1,0)$, $\operatorname{ARIMA}(0,1,2), \operatorname{ARIMA}(2,1,1)$ ve $\operatorname{ARIMA}(2,1,2)$ olarak belirlenmiştir. Tablo 3 'de sol taraftaki satırlarda, en iyi modelin seçimi için aralarında kıyaslama yapılacak aday modeller yer almaktadır. Tablonun en üst satırında her bir sigorta şirketine ait RMSE, Normalized BIC ve Ljung-BoxQ testi significant değerleri yer almaktadır.

Tablo 3'de Aksigorta A.Ş için hesaplanan Ljung-BoxQ testinin significant değeri, tüm aday modeller için 0,05 değerinden büyük olduğu için modellerin doğru aday modeller olarak seçildiği görülebilmektedir. Hisse senetleri günlük kapanış fiyatları serisini en iyi açıklayan ya da veri kalıbı karakteristiğine en iyi uyum gösteren model RMSE ve Normalized BIC değerlerinin karşılaştırılması ile bulunabilmektedir. En küçük RMSE değeri 0,179 olan modellerden, negatif olarak en küçük BIC değerine sahip (-3.373) ARIMA(0,1,0) modeli Aksigorta A.Ş. (AKGRT) hisse senedi kapanış fiyatı serisini en iyi açıklayan model olmaktadır. Anadolu Hayat Emeklilik A.Ş. (ANHYT) için ARIMA(1,1,0), Anadolu Anonim Türk Sigorta Şirketi (ANSGR) için ARIMA(0,1,0), Güneş Sigorta A.Ş.(GUSGR) için ARIMA $(0,1,0)$ ve Ray Sigorta A.Ş. (RAYSG) için $\operatorname{ARIMA}(1,1,2)$, olarak belirlenmiştir. 
Tablo 3. Aksigorta A.Ş., Anadolu Hayat Emeklilik A.Ş. , Anadolu Anonim Türk Sigorta Şirketi, Güneş Sigorta A.Ş., Ray Sigorta A.Ş. İstatistiksel Anlamlılık ve Durağanlık Koşulunu Sağlayan Aday Modelleri

\begin{tabular}{|c|c|c|c|c|c|c|c|c|c|c|c|c|c|c|}
\hline \multirow[b]{2}{*}{$\operatorname{ARIMA}(p, d, q)$} & \multicolumn{2}{|r|}{ AKGRT } & \multicolumn{3}{|c|}{ ANHYT } & \multicolumn{3}{|c|}{ ANSGR } & \multicolumn{3}{|c|}{ GUSGR } & \multicolumn{3}{|c|}{ RAYSG } \\
\hline & RMSE & $\begin{array}{c}\text { Normalized } \\
\text { BIC }\end{array}$ & Sig. RMSE & $\begin{array}{l}\text { Normalized } \\
\text { BIC }\end{array}$ & Sig. & RMSE & $\begin{array}{c}\text { Normalized } \\
\text { BIC }\end{array}$ & Sig. & RMSE & $\begin{array}{l}\text { Normalized } \\
\text { BIC }\end{array}$ & Sig. & RMSE & $\begin{array}{l}\text { Normalized } \\
\text { BIC }\end{array}$ & Sig. \\
\hline ARIMA(0,1,0) & 0,179 & $-3,373$ & $0,218 \quad 0,175$ & $-3,402$ & 0,029 & 0,066 & $-5,377$ & 0,050 & 0,068 & $-5,297$ & 0,241 & 0,067 & $-5,275$ & 0,079 \\
\hline ARIMA(0,1,1) & 0,179 & $-3,370$ & $0,328 \quad 0,175$ & $-3,404$ & 0,264 & 0,066 & $-5,375$ & 0,147 & 0,068 & $-5,295$ & 0,205 & 0,067 & $-5,272$ & 0,058 \\
\hline ARIMA(1,1,0) & 0,179 & $-3,370$ & $0,324 \quad 0,175$ & $-3,405$ & 0,270 & 0,066 & $-5,375$ & 0,148 & 0,068 & $-5,295$ & 0,206 & 0,067 & $-5,272$ & 0,058 \\
\hline ARIMA(1,1,1) & 0,179 & $-3,368$ & $0,301 \quad 0,175$ & $-3,401$ & 0,217 & 0,066 & $-5,374$ & 0,031 & 0,068 & $-5,293$ & 0,150 & 0,067 & $-5,272$ & 0,036 \\
\hline ARIMA(1,1,2) & 0,180 & $-3,357$ & $0,224 \quad 0,175$ & $-3,398$ & 0,161 & 0,066 & $-5,372$ & 0,103 & 0,068 & $-5,291$ & 0,123 & 30,067 & $-5,277$ & 0,194 \\
\hline ARIMA(2,1,0) & 0,179 & $-3,368$ & $0,289 \quad 0,175$ & $-3,401$ & 0,218 & 0,066 & $-5,374$ & 0,114 & 0,068 & $-5,293$ & 0,161 & 0,067 & $-5,272$ & 0,080 \\
\hline ARIMA(0,1,2) & 0,179 & $-3,368$ & $0,290 \quad 0,175$ & $-3,401$ & 0,219 & 0,066 & $-5,373$ & 0,113 & 0,068 & $-5,293$ & 0,161 & 0,067 & $-5,273$ & 0,085 \\
\hline ARIMA(2,1,1) & 0,180 & $-3,361$ & $0,261 \quad 0,175$ & $-3,398$ & 0,167 & 0,066 & $-5,372$ & 0,104 & 0,068 & $-5,291$ & 0,123 & 0,067 & $-5,276$ & 0,193 \\
\hline ARIMA(2,1,2) & 0,180 & $-3,358$ & $0,155 \quad 0,175$ & $-3,397$ & 0,124 & 0,066 & $-5,370$ & 0,009 & 0,068 & $-5,293$ & 0,101 & 0,067 & $-5,274$ & 0,148 \\
\hline
\end{tabular}

Sigorta şirketleri hisse senetleri kapanış fiyatları serilerine en uygun ARIMA modelinin belirlenmesinden sonra, belirlenen ARIMA modelleri kullanilarak, hisse senetlerinin en son kapanış tarihi verisinden itibaren 1 yıllık fiyat tahminleri yapılmıştır. Aşağıda yer alan tahmin grafiklerinde yatay eksende veri sayısı, dikey eksende ise ilgili sigorta şirketine ait kapanış fiyatları yer almaktadır. Ortalama 4000 geçmiş kapanış fiyatı verisinden hareketle 200 iş günü verisi tahmin edilmiştir. Grafiklerin sağ tarafinda yer alan dikey çizgiden itibaren sağ tarafta, tahmin sonuçlarının olması beklenen fiyat artış-azalış yönleri görsel olarak gösterilmektedir.

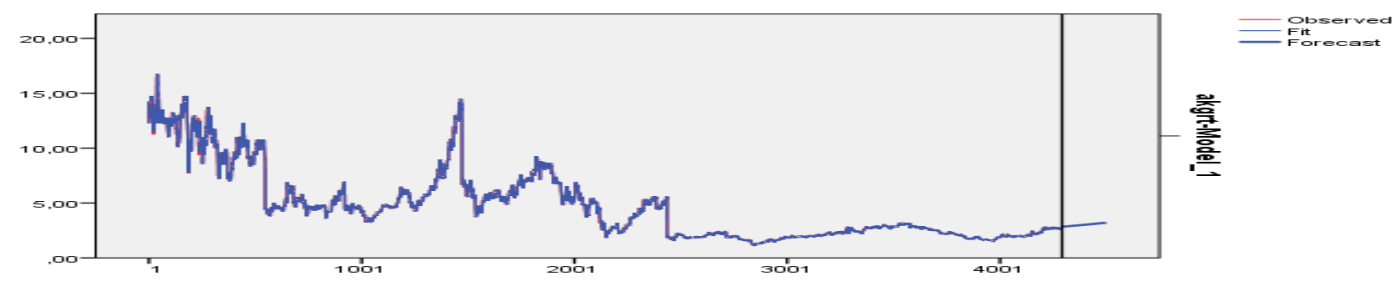

Grafik 16. Aksigorta A.Ş. Geleceğe İlişkin Hisse Senedi Kapanış Fiyatları Tahminleri

Aksigorta A.Ş.'nin 2000 yılı başında ortalama 13 TL civarında seyreden hisse senedi kapanış fiyatı 2017 yılı mayıs ayı sonlarında 2,70 TL civarında değer kaydetmiştir. Sonrasındaki 1 yıllık süreçte yükselişe geçerek 3,20 TL civarında seyretmesi beklenmektedir. 


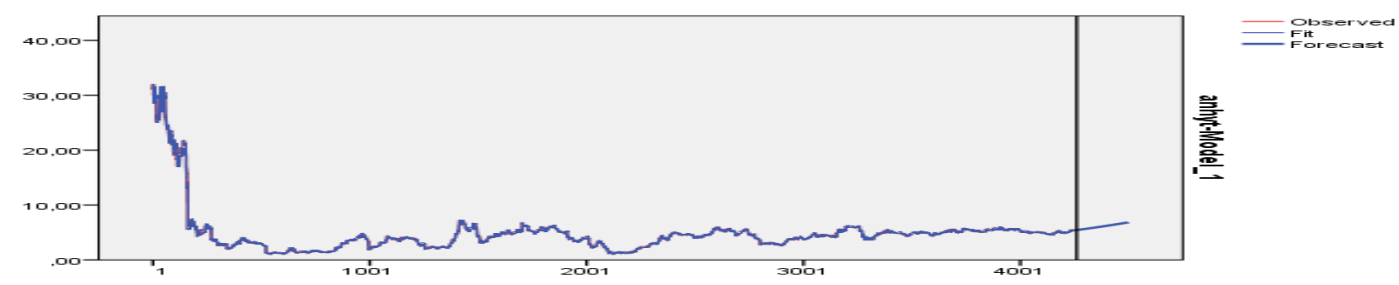

Grafik 17. Anadolu Hayat Emeklilik A.Ş. Geleceğe İlişkin Hisse Senedi Kapanı̧̧ Fiyatları Tahminleri

Anadolu Hayat Emeklilik A.Ş. hisse fiyatları 2000 yılı başlarında ortalama 28 TL seviyelerinde değer kazanmış, sonrasında hisseler, 2017 yılı başlarında ortalama 5 TL bandında seyretmiştir. 2017 Mayıs ayı sonrasındaki tahmin edilen 1 yıllık süreç sonunda 6,5 TL seviyelerinde olması beklenmektedir.

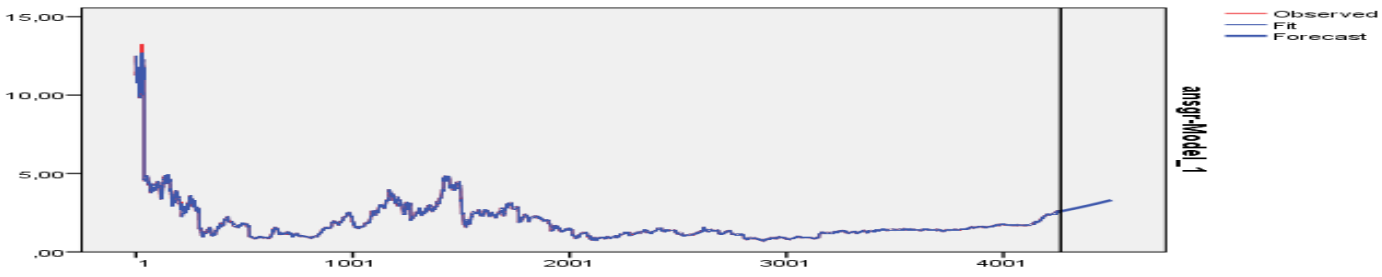

Grafik 18. Anadolu Anonim Türk Sigorta Şirketi Geleceğe İlişkin Hisse Senedi Kapanış Fiyatları Tahminleri

Anadolu Anonim Türk Sigorta Şirketi hisse senetleri 2000 yılı başında ortalama 12 TL seviyesinde değer kazanırken, sonrasında düşüşe geçerek 4 TL sınırı, daha sonra 2 TL sınırı altında bir fiyat seyri göstermiştir. Sonrasında yavaş bir ivmelenme ile 4 TL bandına çıkan hisse değerlerinin tahmin edilen 1 yıllık süreç sonunda 2 TL seviyesinin üzerine çıkması beklenmektedir.

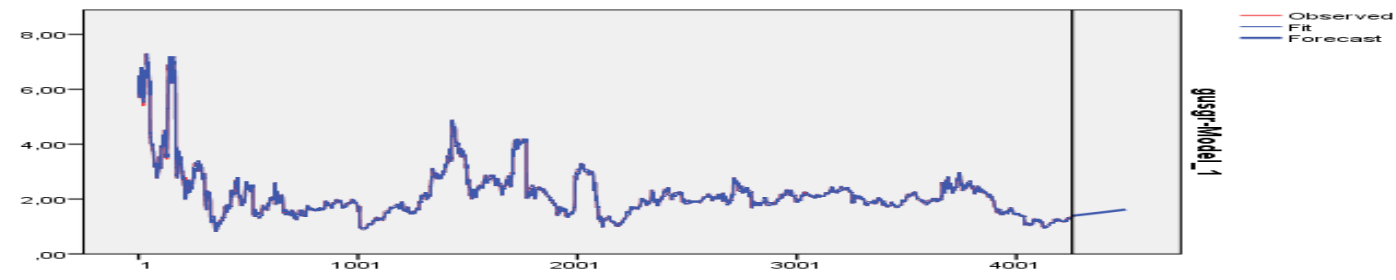

Grafik 19. Güneş Sigorta A.Ş. Geleceğe İlişkin Hisse Senedi Kapanış Fiyatları Tahminleri

Güneş Sigorta A.Ş. hisse senedi fiyatları 2000 yılı başında ortalama 6,5TL olarak gerçekleşmişken, sonrasında 1 TL bandına kadar inmiş ve sonrasında 2005-2009 yılları arasında dalgalı bir grafik sergilemiştir. 2017 yılından sonraki 1 y1llık 2 TL seviyesine çıkması beklenmektedir. 


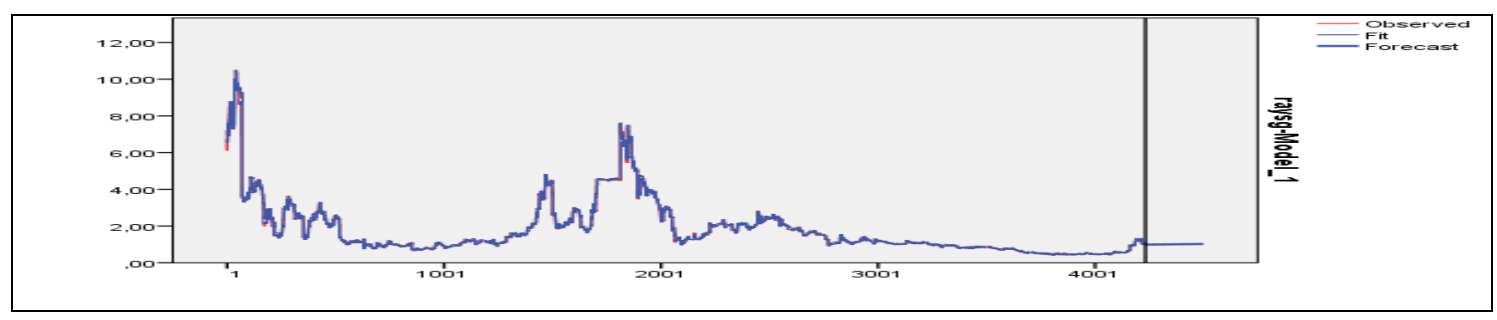

Grafik 20. Ray Sigorta A.Ş. Geleceğe İlişkin Hisse Senedi Kapanış Fiyatları Tahminleri

Ray Sigorta veri seti incelendiğinde artan ve azan trend etkileri gözlenmektedir. 200 yılında 10 TL civarında değer kazanan hisse senedi fiyatları sonrasında düşüşe geçerek $2 \mathrm{TL}$ bandının altına kadar gerilemiştir. 2017 yılı Mayıs ayından sonra 0 TL ile 2 TL arasında değer alması beklenmektedir. Önümüzdeki 1 yıllık süreçte azalış eğiliminde olması öngörülmektedir.

Bu çalışmada 2000 - 2017 yılları arasında sigorta sektöründe yer alan Aksigorta A.Ş., Anadolu Hayat Emeklilik A.Ş., Anadolu Anonim Türk Sigorta Şirketi , Güneş Sigorta A.Ş. , Ray Sigorta A.Ş. 'ye ait günlük kapanış fiyatları incelenmiş 2017'nin son 6 ayı ile 2018 yılının ilk 6 ayını kapsayacak şekilde toplam bir yıllık fiyat tahmini yapılmıştır. Aşağıdaki grafiklerde 2017 yılının son 6 ayında gerçekleşen fiyatlar ile tahmin edilen fiyatlar karşılaştırılmıştır. Yatay eksen 1 yıllık tahmin sürecini günlük kapanış fiyatları bazında göstermektedir. Dikey eksen de ise fiyat değerleri yer almaktadır. Grafiklerde yer alan mavi çizgi tahmin doğrusunu, mor çizgi ise gerçekleşen fiyat eğrisini göstermektedir. En üstteki yeşil çizgi üst fiyat tahmin limitini, altta yer alan sarı çizgi ise alt fiyat tahmin limitini göstermektedir. Ekonomik kriz, savaş vb. gibi uç durumlar olmadığı sürece tüm ekonomik, siyasal, makro ve mikro şartlar düzenli seyrettiğinde hisse senedi kapanış fiyatlarının alt ve üst limitler arasında olması beklenmektedir.

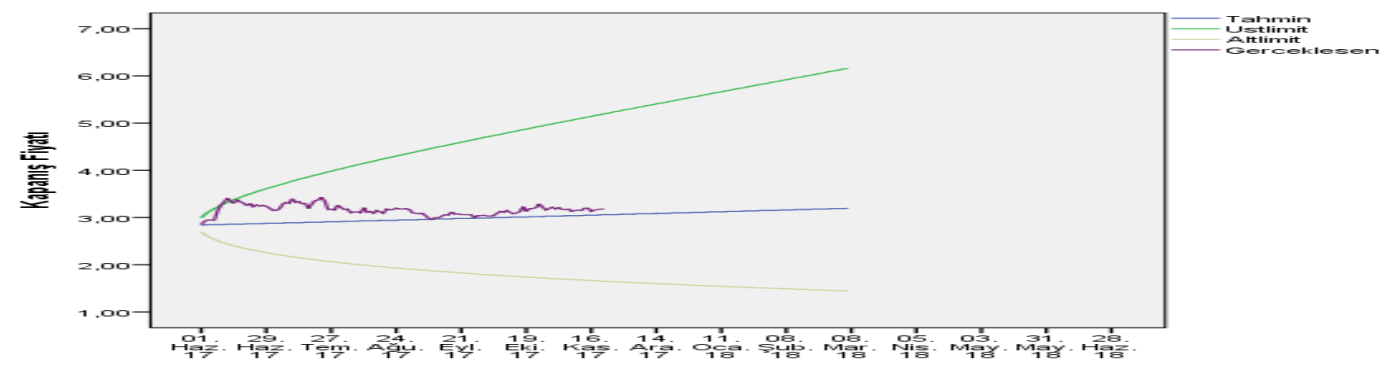

Grafik 21. Aksigorta A.Ş. Haziran 2017-Haziran 2018 Hisse Senedi Fiyat Tahminleri

Grafik 21. incelendiğinde mor renkli çizgi ile gösterilen Aksigorta A.Ş. hisse senetleri kapanış fiyatları Haziran 2017- Aralık 2017 tarihleri arasında, tahmin edilen alt ve üst limit fiyat aralıklarının içinde kalmaktadır. Grafikte mavi renk ile gösterilen tahmin doğrusu çizgisi hisse senedi kapanış fiyatlarının artış trendi etkisinde yükseliş eğiliminde olmasının beklendiğini ifade etmektedir. Ancak 2017 Haziran ayında fiyatların yeşil renk ile gösterilen üst limit çizgisini aşmasının sebepleri temel analiz göstergeleri yardımıyla incelenmelidir. $\mathrm{Bu}$ çalışmada şirketlere ait gelecek fiyat tahminleri bir yıllık yapılmış olup, Haziran 2018 tarihine kadar aynı ivme ile artış göstermesi beklenmektedir. 


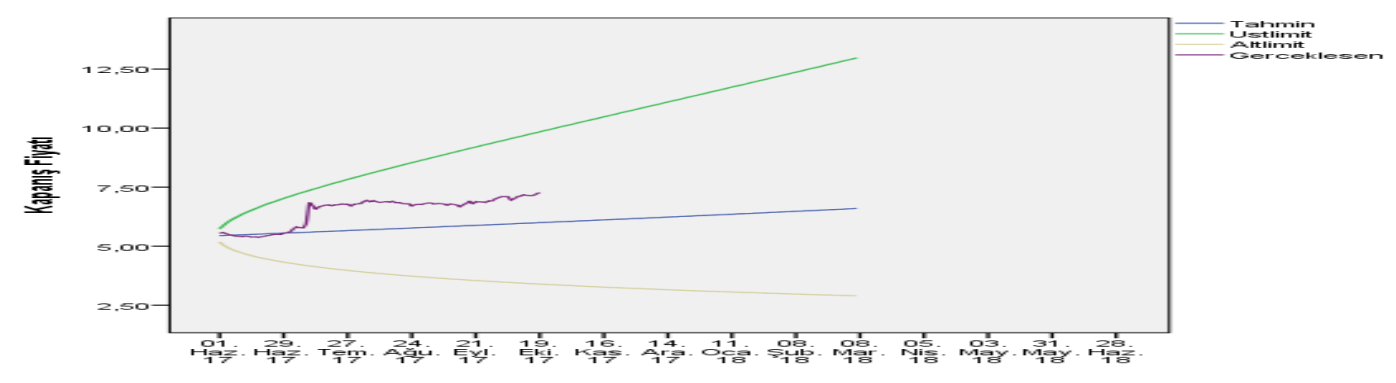

Grafik 22. Anadolu Hayat Emeklilik A.Ş. Haziran 2017-Haziran 2018 Hisse Senedi Fiyat Tahminleri

Grafik 22'de gösterilen Anadolu Hayat Emeklilik A.Ş.'ye ait Haziran 2017- Aralık 2017 tarihleri arasında gerçekleşen kapanış fiyatları, mor renkli çizgi ile gösterilmektedir. Gerçekleşen kapanış fiyatları, mavi renk ile gösterilen tahmin doğrusu ile aynı yönlü hareket etmektedir. Alt ve üst fiyat limitleri arasında kalan fiyat verilerinin 2018 yılı Haziran ayına kadar artış göstermesi beklenmektedir.

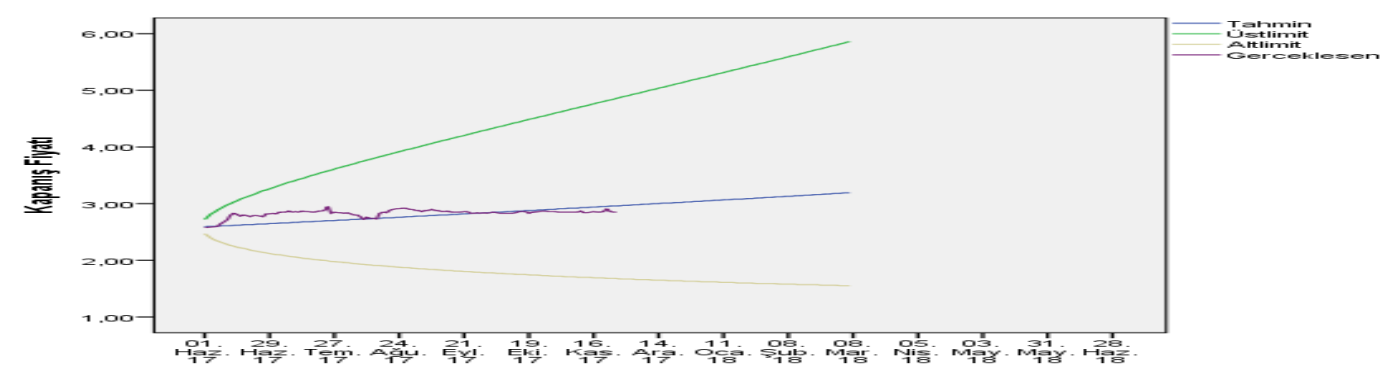

Grafik 23. Anadolu Anonim Türk Sigorta Şirketi Haziran 2017-Haziran 2018 Hisse Senedi Fiyat Tahminleri

Anadolu Anonim Türk Sigorta Şirketi hisse senedi kapanış fiyatları Haziran 2017 itibari ile fiyat tahmin eğrisini zaman zaman kesmiş ve fiyat tahmin doğrusuna çok yakın değerler almıştır. Mor renk ile gösterilen gerçekleşmiş fiyat değerleri, tahmin doğrusuna yakın ve paralel değerler almıştır. Her iki çizgi grafiği de üst ve alt limitler arasında kalmaktadır. 2018 yılı haziran ayına kadar yapılan hisse senedi fiyat tahminleri doğrultusunda hisse fiyatlarının artması beklenmektedir. 


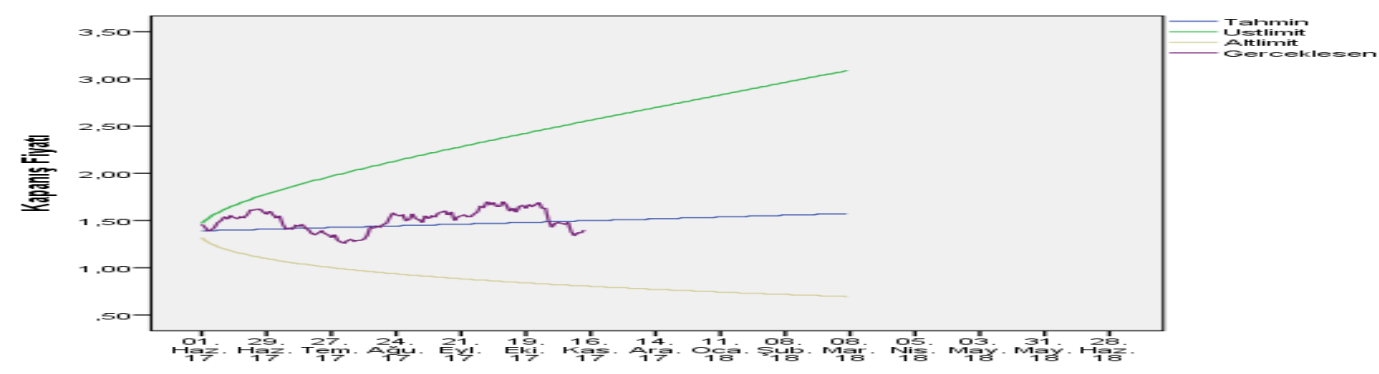

Grafik 24. Güneş Sigorta A.Ş. Haziran 2017-Haziran 2018 Hisse Senedi Fiyat Tahminleri

Grafik 24'de, Güneş Sigorta A.Ş. hisse senetleri kapanış fiyatı rakamları Haziran 2017 - Aralık 2017 zaman diliminde alt ve üst fiyat limitlerinin arasında ve dalgalı bir grafik görüntüsü sergilemektedir. Fiyat tahmin doğrusu ile gerçekleşen rakamların oluşturduğu doğrular, birbirlerine yakın seyir göstermektedir. Gerçekleşen fiyat çizgisi ile tahmin edilen fiyat çizgisi birbirine yakın değerler almaktadır.2018 y1lı ikinci çeyreğine kadar, hisse fiyatlarının artış eğiliminde olması beklenmektedir.

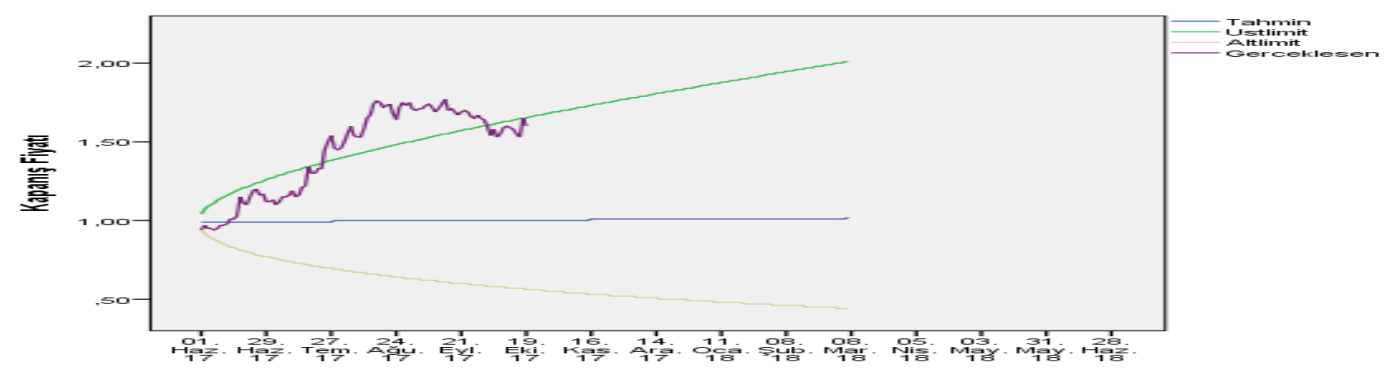

Grafik 25. Ray Sigorta A.Ş. Haziran 2017-Haziran 2018 Hisse Senedi Fiyat Tahminleri

Grafik 25’de Ray Sigorta A.Ş.'nin mor renk ile belirtilen gerçekleşmiş hisse senedi kapanış fiyatları modelin tahmin aralığının dışına çıkmıştır. Buna göre gerçekleşen fiyatlar, 1 TL civarında seyreden hisse senedi fiyatları 1,50 TL'nin üzerinde değer kazanmış ve yine 1,50 TL seviyesine gerilemiştir. Bu ani ve hılı yükselmenin sebepleri temel analiz ile desteklenmelidir. Sonuçlardan hareketle hisse senedi kapanış fiyatlarının 1 TL civarında seyretmesi beklenmektedir.

\section{SONUÇ}

$\mathrm{Bu}$ çalışmada kullanılan Box-Jenkins/ARIMA modelinin, Borsa İstanbul'da kote sigorta ve bireysel emeklilik şirketlerinden seçilen Aksigorta A.Ş (AKGRT), Anadolu Hayat Emeklilik A.Ş. (ANHYT), Anadolu Anonim Türk Sigorta Şirketi (ANSGR), Güneş Sigorta A.Ş. (GUSGR) ve Ray Sigorta A.Ş. (RAYSG) şirketlerine ait 2000 - 2017 yılları arasındaki tarihsel hisse senedi kapanış fiyatlarını içeren zaman serileri incelenmiştir. Grafik 22'de gösterilen Anadolu Hayat Emeklilik A.Ş. (ANHYT), Grafik 23'de gösterilen Anadolu 
Anonim Türk Sigorta Şirketi (ANSGR) ve Grafik 24'de gösterilen Güneş Sigorta A.Ş. (GUSGR) şirketlerine ait tahmin ve gerçekleşen fiyat değerlerini içeren grafikler incelendiğinde tahmin fiyatları ve gerçekleşen fiyatların birbirine yakın değerler aldıkları gözlemlenmektedir. Alt ve üst fiyat limitlerini aşmayan bu üç şirketin hisse senedi fiyat tahmininde Box-Jenkins/ARIMA modeli kullanıldığında doğru sonuçlar verdiği belirlenmiştir. Grafik 21'de gösterilen Aksigorta A.Ş (AKGRT) 'ye ait grafikte, 2017 Haziran ayına ait fiyat değerlerinin üst sınırı aştı̆̆ı gözlemlenmiştir. Grafik 25'de gösterilen Ray Sigorta A.Ş. (RAYSG) 'ye ait grafikte de üst fiyat limitini oldukça aşan bir gerçekleşme rakamları gözlemlenmiştir. Bu iki şirkete ait fiyat hareketlerinin temel analiz yöntemi ile birlikte incelenmesi ve ani fiyat hareketlerinin şirketlere ait finansal göstergeler ile karşılaştırılması gerekmektedir.

Box-Jenkins/ARIMA yöntemi hisse senedi fiyat tahmininde kullanıldığında doğru sonuçlar vermektedir. Özellikle hisse senedi fiyatları, öngörülmesi ve modellenmesi oldukça zor işleyişler olduğundan, zaman serisi verilerinin durağan olması yöntemin ön koşuludur. Durağanlık, istikrarlı veri seti anlamına gelmektedir. İstikrar, tahminlerin gerçekleşmesi için bir gereklilik olmakla birlikte, zaman serileri analizi için mutlaka sağlanmalıdır. Durağanlık sağlanamazsa, başka bir deyişle incelenen zaman aralığında ortalama ve varyans değişken ise zaman serileri için model geliştirmek oldukça zorlaşmaktadır. Durağan olmayan zaman serilerini kullanarak elde edilen sonuçlar, var olmayan eğilimleri ya da değişkenler arası ilişkileri gösterebileceğinden yanıltıcı olabilmektedir. Zaman serisinde trend ve mevsimsellik varsa arındırılabilir; seride şok olarak tanımlanabilecek ani iniş-çıkışlar varsa, zaman serisi analizi, volatilite modelleme teknikleri ile desteklenmelidir.

\section{KAYNAKLAR}

Akgül, Iş11 (2003), Zaman Serilerinin Analizi ve ARIMA Modelleri, 1. Baskı, Der Yayınevi, İstanbul

Bleikh, Haim Y. - Young, Warren L. (2014), Time Series Analysis and Adjustment, 1st Edition, Gower Publishing Limited, UK

Box, George E. P. - Jenkins, Gwilym M., (1976), Time Series Analysis Forecasting and Control, Rev.Ed.,Holden-Day Inc., USA

Chai T- Draxler R.R., (2014) "Root Mean Square Error (Rmse) or Mean Absolute Error (MAE)-Argumants Against Avaiding RMSE in the Literature”, Geoscientific Model Development, V:7, Jun, pp. 1247-1250.

Duyar, İbrahim (1995) “Model Seçiminde Bayesian Yaklaşım”, Ankara Üniversitesi Eğitim Bilimleri Fakültesi Dergisi, 1995, C:28, S:2, ss.95-106.

Grene, William H., (2008), Econometric Analysis, 8th Edition, Pearson Education, Inc., USA

Gujarati, Damodar N., (2010), basic econometrics, McGraw-Hill/Irwin, New York, (Ümit Şenesen - Gülay Günlük Şenesen, Temel Ekonometri, Literatür Yayıncılık, İstanbul, 2010, ss. 972) 
Gürsakal, Necmi (2013), Çıkarımsal İstatistik, 5. Baskı, Dora Basım-Yayın Dağıtım, Bursa

Hua, Goh Bee- Pin, Teo Ho (2000), "Forecasting Construction Industry Demand, Price and Productivity in Singapore: The Box-Jenkins/ARIMA Approach”, Construction Management and Economic, Vol:18 (5), October, pp. 607-618

Kennedy, Peter, (2003), A Guide to Econometrics, 5th Edition, The MIT Press, Cambridge, UK.

Lindsay, J.K., (2004) Statistical Analysis of Stochastic Processes in Time, Cambridge University Press, UK

Mećiarová, Zuzana (2007), “Modeling and Forecasting Seasonal Time Series”, Journal of Information, Control and Management System, Vol.5 (1), pp. 73-80

Ngo, Theresa Hoang Diem, (2013), “The Box-Jenkins/ARIMA Methodology for Time Series Models”, Warner Bros. Entertainment Group, Burbank, CA, SAS Global Forum

O’Donovan, Thomas M. (1983), Short Term Forecasting: An Introduction to the BoxJenkins/ARIMA Approach,, Wiley, New York

Panagopoulos’ Athanasios Aris- Chalkiadakis, Georgios- Koutroulis, Eftichios (2012)

"Predicting the Power Output of Distributed Renewable Energy Resources within a Broad Geographical Region” Workshop Item, Ecai

Pankratz, Alan, (1983) Forecasting with Univariate Box-Jenkins Models: Concepts and Cases, John Wiley \& Sons, Inc., Hoboken, NJ, USA

Schwarz , Gideon, (1978) "Estimating the Dimension of a Model”, The Annals of Statistics, V:6 (2), pp. 461-464.

Sevütekin, Mustafa - Nargeleçekenler, Mehmet (2010) Ekonometrik Zaman Serileri Analizi, 3.Baskı, Nobel Yayın Dağıtım, Bursa

Shumway, Robert H - Stoffer, David S., (2006), Time Series Analysis and Its Applications with R Examples, 3th Edition, Springer Science+Business Media, LLC, USA

Stanković, Jelena - Delias, Pavlos - Marinkovic, Srdan - Rochhia, Sylvie, (2017), Tools and Techniques for Economic Decision Analysis, IGI Global, USA 